\title{
ANALISIS PENGARUH KOMUNIKASI EFEKTIF DAN KOORDINASI TERHADAP MOTIVASI KERJA DAMPAKNYA TERHADAP KINERJA KARYAWAN PT GARUDA INDONESIA (Persero) Tbk
}

\author{
Anik Ariyanti \\ Dosen STIE IPWIJA \\ ariyanti.anik@yahoo.co.id
}

\begin{abstract}
This study aims to determine the effect of effective communication and coordination through work motivation on the performance of employees of PT Garuda Indonesia (Persero) Tbk. The sample in this study amounted to 100 people or $25 \%$ of the total population of 400 people. This research uses quantitative descriptive analysis method. Methods of data analysis using the Classical Assumption Test, Regression Test, Determination Coefficient, Hypothesis Test and Path Analysis. The test results show that effective communication and direct coordination have a positive and significant effect on work motivation. Effective communication and direct coordination have a positive and significant effect on performance. Indirectly effective communication and coordination through work motivation have no significant effect on performance. The total effect of effective communication on performance through work motivation is equal to 0.327 and the effect of coordination on performance through work motivation is 0.588 . The total value of $R^{2}$ is 0.593 or $59.3 \%$, meaning that communication is effective, coordination and motivation are able to explain the performance of $59 \%$, the remaining $40.7 \%$ is explained by other variables.
\end{abstract}

Keywords: effective communication, coordination, work motivation and performance

\section{PENDAHULUAN}

Sebagai perusahaan penerbangan pembawa bendera Indonesia yang mempromosikan Indonesia kepada dunia, PT Garuda Indonesia (Persero) Tbk., mempunyai misi untuk menunjang ekonomi dengan memberikan pelayanan yang profesional kepada masyarakat. Visi utamanya adalah menjadi perusahaan penerbangan yang handal dengan menawarkan pelayanan yang berkualitas kepada masyarakat dunia menggunakan keramahan Indonesia.

Kepuasan pelanggan (customer satisfaction) adalah menjadi tujuan PT Garuda Indonesia (Persero) Tbk., dengan menghidupkan kembali budaya perusahaan yaitu Higher Seat Load Factor, Improve on time Performance, menambah penghasilan, dan profitabilitas perusahaan. Untuk mencapai visi, misi dan tujuan tersebut, PT Garuda Indonesia (Persero) Tbk. membutuhkan team work/kerjasama yang baik. Dalam membentuk "team work" yang baik dibutuhkan komunikasi, kerjasama dan koordinasi (3-K).

$$
\text { Komunikasi adalah sebuah }
$$

kemutlakan dalam menjalankan roda bisnis perusahaan tanpa komunikasi tidak akan terbentuk kerjasama. PT Garuda Indonesia (Persero) Tbk., memandang bahwa komunikasi yang efektif sangatlah penting. Selama ini bentuk komunikasi yang terjadi belum sepenuhnya efektif karena masalah sering muncul disebabkan adanya miskomunikasi. 
Selain komunikasi yang efektif, peranan koordinasi juga menjadi sangat penting. Koordinasi merupakan kegiatan untuk mengimbangi dan menggerakan tim dengan memberikan lokasi kegiatan pekerjaan yang cocok dengan masing-masing dan menjaga agar kegiatan ini dilakukan sesuai dengan tujuan yang telah ditetapkan sebelumnya. (Hasibuan, 2015).

Selain itu, faktor motivasi kerja juga sangat penting bagi perusahaan untuk mendukung peningkatan kinerja. Motivasi kerja merupakan dorongan psikologis yang mengarahkan seseorang ke arah suatu tujuan, juga menjadi dorongan (driving force) terhadap seseorang agar mau melaksanakan sesuatu. (Kartini Kartono, 2014)

Berdasarkan uraian di atas, maka peneliti ingin mengetahui lebih dalam mengenai komunikasi efektif, koordinasi pengaruhnya terhadap motivasi kerja dan dampaknya terhadap kinerja karyawan PT Garuda Indonesia (Persero) Tbk.

\section{PERMASALAHAN}

Permasalahan yang diangkat dalam penelitian ini adalah tentang kurang efektifnya bentuk komunikasi, koordinasi, dan motivasi di lingkungan PT Garuda Indonesia (Persero) Tbk., sehingga berpengaruh terhadap kinerja. Komunikasi efektif di lingkungan PT Garuda Indonesia (Persero) Tbk., belum optimal dalam memenuhi syarat REACH (respect, empathy, audible, clarity, dan humble). Masalah koordinasi juga menjadi perhatian khusus untuk mendukung tercapainya komunikasi yang efektif sehingga mampu mempengaruhi motivasi kerja dan berdampak pada peningkatkan kinerja.

\section{RUMUSAN MASALAH}

Rumusan masalah dalam penelitian ini adalah:

1. Apakah komunikasi efektif berpengaruh terhadap motivasi kerja karyawan PT Garuda Indonesia (Persero) Tbk?

2. Apakah koordinasi berpengaruh terhadap motivasi kerja karyawan PT Garuda Indonesia (Persero) Tbk?

3. Apakah komunikasi efektif berpengaruh terhadap kinerja karyawan PT Garuda Indonesia (Persero) Tbk?

4. Apakah koordinasi berpengaruh terhadap kinerja karyawan PT Garuda Indonesia (Persero) Tbk?

5. Apakah motivasi kerja berpengaruh terhadap kinerja karyawan PT Garuda Indonesia (Persero) Tbk.

6. Apakah komunikasi efektif melalui motivasi kerja berpengaruh terhadap kinerja karyawan PT Garuda Indonesia (Persero) Tbk?

7. Apakah koordinasi melalui motivasi kerja berpengaruh terhadap kinerja karyawan PT Garuda Indonesia (Persero) Tbk?

\section{TINJAUAN TEORI}

\section{Komunikasi Efektif}

Komunikasi efektif adalah pertukaran informasi, ide, kepercayaan, perasaan dan 
sikap antara dua orang (komunikator dan komunikan) atau berupa kelompok yang hasilnya sesuai dengan harapan dari respon yang diterima dan mampu menghasilkan perubahan sikap (attitude change) dengan penyampaian informasi, menghibur, ataupun membujuk orang yang terlibat dalam komunikasi tersebut. (Hardjana, 2003)

Hukum komunikasi “ $R E A C H$ ” yang meliputi Respect (sikap menghargai), Empathy (kemampuan mendengar), Audible (dapat didengarkan atau dimengerti dengan baik), Clarity (jelas) dan Humble (rendah hati) (Aribowo Prijosaksono, 2007)

\section{Koordinasi}

Koordinasi menurut Awaluddin Djamin dalam Hasibuan (2011:86) diartikan sebagai suatu usaha kerjasama antara badan, instansi, unit dalam pelaksanaan tugas-tugas tertentu, sehingga terdapat saling mengisi, saling membantu dan saling melengkapi.

Menurut Hadayaningrat (1990) fungsi koordinasi adalah sebagai upaya yang mengarahkan dan menyatukan kegiatan yang mengandung makna adanya keterpaduan (integrasi) yang dilakukan secara serasi dan simultan/sinkronisasi.

\section{Motivasi Kerja}

Menurut Hasibuan (dalam Edy Sutrisno, 2016) motivasi kerja merupakan suatu perangsang keinginan dan daya penggerak kemauan bekerja seseorang karena setiap motivasi mempunyai tujuan tertentu yang ingin dicapai.

\section{Menurut Steers \& Porter (dalam} Miftahun \& Sugiyono, 2010) bahwa motivasi kerja adalah suatu usaha yang dapat menimbulkan suatu perilaku, mengarahkan perilaku, dan memelihara atau mempertahankan perilaku sesuai dengan lingkungan kerja dalam organisasi.

Malayu S.P. Hasibuan memberikan penjelasan tentang teori Maslow yang dikenal dengan Hierarki Kebutuhan dari Maslow, meliputi lima kebutuhan yaitu: kebutuhan fisiologis, kebutuhan rasa aman, kebutuhan sosial, kebutuhan penghargaan dan kebutuhan aktualisasi diri.

\section{Kinerja}

Kinerja merupakan perwujudan dari kemampuan dalam bentuk karya nyata. Kinerja merupakan hasil kerja yang dicapai karyawan dalam mengemban tugas dan pekerjaan yang berasal dari organisasi. (Priansa, 2014:269).

Kinerja berasal dari kata job performance (prestasi kerja). Kinerja merupakan hasil kerja secara kualitas dan kuantitas yang dicapai oleh seorang pegawai dalam melaksanakan tugasnya sesuai dengan tanggung jawab yang diberikan kepadanya (Mangkunegara, 2015).

Beberapa faktor yang mempengaruhi kinerja adalah kemampuan dan motivasi. Secara psikologis, kemampuan (ability) pegawai terdiri dari kemampuan potensi (IQ) di atas rata-rata (IQ 110-120) dengan 
pendidikan memadai untuk jabatannya dan terampil dalam mengerjakan tugasnya. Pegawai harus ditempatkan pada pekerjaan yang sesuai dengan keahliannya (the right man in the right place, the man on the right job). Motivasi merupakan sikap (attitude) dari pegawai dalam menghadapi situasi (situation) motivasi merupakan kondisi yang menggerakkan dari pegawai yang terarah untuk mencapai tujuan organisasi (tujuan kerja).

Menurut Edison (2016) dimensi kinerja meliputi: target (indikator terhadap capaian kerja), kualitas (mutu yang dihasilkan yang menjadi penguat), waktu penyelesaian (ketepatan waktu dalam penyelesaian tugas), taat asas (cara yang benar dan transparan yang dapat dipertanggungjawabkan).

\section{KERANGKA BERPIKIR}

Komunikasi efektif berpengaruh terhadap peningkatan kinerja. Semakin efektif komunikasi yang dilakukan dalam organisasi maka semakin efektif mempengaruhi kinerja. Hal ini sependapat dengan penelitian oleh Ratih Yopita (2015) bahwa terdapat pengaruh yang cukup dan signifikan antara Komunikasi Efektif (X) terhadap Kinerja (Y) pada PT Serpong Media Utama, Tangerang Selatan. Hasil perhitungan koefisien determinasi sebesar $23,2 \%$ yang artinya Komunikasi Efektif (X) berpengaruh terhadap Kinerja (Y) sebesar $23,2 \%$ dan sisanya $76,8 \%$ kinerja karyawan dipengaruhi faktor lainnya.
Motivasi kerja yang tinggi mampu mempengaruhi tingkat kinerja karyawan. Penelitian yang mendukung pendapat ini adalah penelitian Syarah Amalia dan Mahendra Fakhri (2016) menyimpulkan bahwa motivasi secara parsial berpengaruh signifikan terhadap kinerja karyawan pada PT Gramedia Asri Media Cabang Emerald Bintaro. Berdasarkan koefisien determinasi dihasilkan pengaruh motivasi sebesar $68,6 \%$ dan sisanya $31,94 \%$ dipengaruhi oleh variabel lain yang tidak diteliti.

Pendapat lain oleh Uep Tatang Sontani (2014) dalam penelitian yang menyimpulkan bahwa pengaruh motivasi terhadap kinerja pada PT X Bekasi berada pada kategori tinggi. Hasil perhitungan menunjukkan bahwa kinerja dipengaruhi motivasi sebesar $33,5 \%$ dan sisanya $66,5 \%$ dipengaruhi faktor lain.

Kerangka pemikiran penelitian ini dapat digambarkan sebagai berikut:

Gambar 1

Kerangka Pemikiran

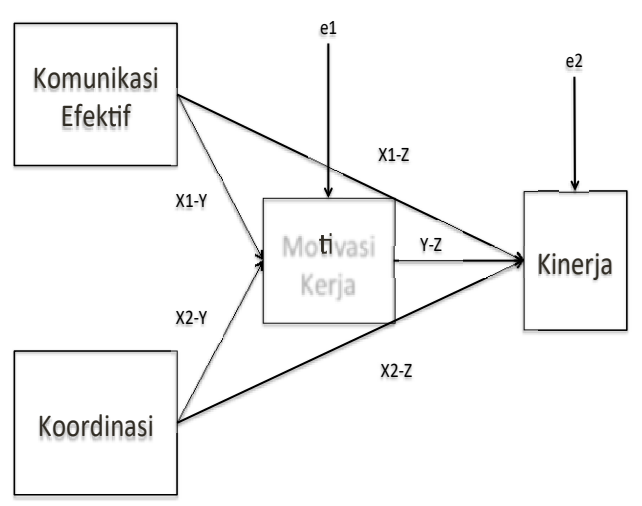

Sumber: data diolah

\section{HIPOTESIS}

Hipotesis penelitian ini adalah: 
$\mathrm{H}_{1}$ : Komunikasi efektif berpengaruh terhadap motivasi kerja karyawan PT Garuda Indonesia (Persero) Tbk.

$\mathrm{H}_{2}$ : Koordinasi berpengaruh terhadap motivasi kerja karyawan PT Garuda Indonesia (Persero) Tbk.

$\mathrm{H}_{3}$ : Komunikasi efektif berpengaruh terhadap kinerja karyawan PT Garuda Indonesia (Persero) Tbk.

$\mathrm{H}_{4}$ : Koordinasi berpengaruh terhadap kinerja karyawan PT Garuda Indonesia (Persero) Tbk.

$\mathrm{H}_{5}$ : Motivasi kerja berpengaruh terhadap kinerja karyawan PT Garuda Indonesia (Persero) Tbk.

$\mathrm{H}_{6}$ : Komunikasi efektif berpengaruh terhadap kinerja melalui motivasi kerja karyawan PT Garuda Indonesia (Persero) Tbk.

$\mathrm{H}_{7}$ : Koordinasi berpengaruh terhadap kinerja melalui motivasi kerja karyawan PT Garuda Indonesia (Persero) Tbk.

\section{METODOLOGI PENELITIAN}

Metode penelitian yang digunakan dalam penelitian ini adalah metode penelitian deskriptif kuantitatif yaitu dengan cara mencari informasi tentang gejala yang ada, didefinisikan dengan jelas tujuan yang akan dicapai, merencanakan cara pendekatannya, mengumpulkan data sebagai bahan untuk membuat laporan. (Sugiyono, 2014).

\section{POPULASI DAN SAMPEL}

Populasi penelitian ini berjumlah 400 orang karyawan PT Garuda Indonesia
(Persero) Tbk. Sampel penelitian ini sebesar 100 orang atau $25 \%$ dari total populasi (400). Hal ini sesuai pendapat Arikunto (2016) Jika jumlah populasi lebih dari 100 maka sampel yang diambil sebesar $10 \%-15 \%$ atau $20 \%$ $25 \%$.

\section{IDENTIFIKASI VARIABEL}

Variabel penelitian ini diidentifikasi sebagai berikut:

1. Variabel Eksogen atau independen adalah variabel yang mempengaruhi variabel dependen dan disimbolkan dengan $\mathrm{X}$, yaitu Komunikasi Efektif $\left(\mathrm{X}_{1}\right)$ dan Koordinasi $\left(\mathrm{X}_{2}\right)$.

2. Variabel Antara atau Intervening adalah variabel mediasi yaitu variabel yang menghubungkan sebuah variabel independen utama pada variabel dependen dan disimbolkan dengan $Y$, yaitu Motivasi $\operatorname{Kerja}(\mathrm{Y})$.

3. Variabel Endogen atau dependen adalah variabel yang dipengaruhi atau yang menjadi akibat karena adanya variabel bebas dan disimbolkan Z, yaitu Kinerja (Z). (Sugiyono, 2012)

\section{Definisi Operasional dan Indikator Variabel}

1. Variabel Kinerja $(Z)$

Kinerja adalah hasil kerja yang dicapai oleh karyawan baik secara kualitas maupun kuantitas sesuai dengan tanggung jawab mereka (Mulyadi, 2015:63). Indikator kinerja meliputi: kemampuan, keterampilan, pengetahuan, kualitas, dan kuantitas. 
2. Variabel Motivasi Kerja (Y)

Motivasi kerja merupakan daya dorong bagi seseorang untuk memberikan kontribusi yang sebesar mungkin demi keberhasilan organisaso mencapai tujuan (Siagian, 2015). Indikator motivasi kerja adalah: dorongan, semangat, kebutuhan, dukungan dan penghargaan.

3. Variabel Komunikasi Efektif $\left(\mathrm{X}_{1}\right)$ dan Koordinasi $\left(\mathrm{X}_{2}\right)$

Komunikasi efektif adalah komunikasi yang mampu menghasilkan perubahan sikap (attitude change) pada orang yang terlibat dalam komunikasi. Indikator komunikasi efektif adalah respect (respek), empathy (empati), audible (dapat didengar), clarity (jelas), dan humble (rendah hati). (Prijosaksono, 2012)

Koordinasi adalah suatu usaha yang sinkron dan teratur untuk menyediakan jumlah dan waktu yang tepat, dan mengarahkan pelaksanaan untuk menghasilkan suatu tindakan yang seragam dan harmonis pada sasaran yang telah ditentukan. Indikator koordinasi meliputi mengarahkan, kesatuan, kesepakatan, keseimbangan, dan kerukunan. (G.R Terry dalam Hasibuan, 2014:85)

\section{Uji Validitas dan Reliabilitas}

Uji validitas digunakan untuk mengukur sah atau valid tidaknya suatu kuesioner. Kriteria uji validitas adalah jika $r$ hitung>rtabel, maka butir pernyataan tersebut valid. Untuk menentukan $r$ tabel dengan $\mathrm{df}=2$ pada signifikansi 5\%. (Ghozali, 2016).

Uji reliabilitas dilakukan untuk mengetahui sejauhmana instrumen dapat memberikan hasil pengukuran yang konsisten, apabila pengukuran dilakukan berulang-ulang. Untuk melihat tingkat reliabilitas data, SPSS memberikan fasilitas untuk mengukur yaitu jika Cronbach Alpha>0,6. (Nunnally dalam Ghozali, 2016).

\section{METODE ANALISIS DATA ANALISIS DESKRIPTIF}

Analisis deskriptif adalah kegiatan menyimpulkan data mentah dalam jumlah yang besar sehingga hasilnya dapat ditafsirkan. Cara menilai variabel independen $(\mathrm{X})$ dan variabel dependen (Y) dilakukan dengan menghitung nilai rata-rata atau mean setiap variabel dengan mengukur nilai tertinggi dan terendah. $(1 \times 10=10)$ dan nilai tertinggi $(5 \times 10=50)$. Perhitungan interval $=50-10 / 5=8$. Sehingga dapat diterangkan sebagai berikut:

Tabel 1

Kriteria Rata-Rata

\begin{tabular}{|l|l|}
\hline Nilai & Kriteria \\
\hline $10-18$ & Tidak Baik \\
$18-26$ & Kurang Baik \\
$26-34$ & Cukup \\
$34-42$ & Baik \\
$42-50$ & Sangat Baik \\
\hline
\end{tabular}

Sumber: data diolah

\section{UJI ASUMSI}

\section{Uji Normalitas}

Uji normalitas bertujuan untuk menguji apakah dalam model regresi, variabel terikat dan variabel bebas memiliki distribusi 
normal. Uji normalitas dalam penelitian ini menggunakan grafik normal Probability Plot dengan melihat penyebaran titik-titik pada sumbu diagonal dari grafik.

\section{Uji Multikolinieritas}

Uji multikolinieritas bertujuan untuk menguji apakah dalam model ditemukan adanya korelasi antar variabel bebas (independen) atau tidak. Pengujian multikolinieritas dilakukan dengan melihat nilai Tolerance dan nilai Variance Inflance Factor (VIF) (Ghozali, 2014).

\section{Uji Heteroskedastisitas}

Uji heteroskedastisitas bertujuan untuk menguji dalam model regresi terjadi ketidaksamaan varians dari residual satu pengamatan ke pengamatan yang lain. Untuk mengetahui terjadi heteroskedastisitas atau tidak dengan melihat Grafik Plot. Tidak terjadi heteroskedastisitas yaitu apabila tidak ada pola yang jelas, serta titik-titik menyebar di atas dan di bawah angka 0 pada sumbu $Y$.

\section{Regresi Linier Berganda}

Analisis regresi berganda digunakan untuk menganalisis besarnya pengaruh variabel independen yang jumlahnya lebih dari dua terhadap variabel dependen. (Suharyadi dan Purwanto, 2004).

\section{Koefisien Determinasi $\left(R^{2}\right)$}

Koefisien determinasi digunakan untuk melihat seberapa besar kontribusi variabel-variabel independen secara bersama dalam menerangkan variabel dependen dimana nilai $\mathrm{R}^{2}$ berkisar antara 0 sampai 1 atau $\left(0 \leq \mathrm{R}^{2}\right.$ $\leq 1)$.

\section{Uji Hipotesis}

Uji F

Uji F untuk mengetahui apakah variabel independen secara bersama-sama mempunyai pengaruh terhadap variabel dependen/terikat. Hipotesis alternatif akan diterima jika nilai $F_{\text {hitung }}>F_{\text {tabel }}$ atau nilai probabilitas sig $<0,05$.

Uji t

Uji t dilakukan untuk mengetahui pengaruh variabel independen secara individual dalam menerangkan variasi variabel dependen. Kriteria pengujian hipotesis adalah jika nilai sig $\mathrm{t}(\mathrm{p}=$ value $)<0,05$ maka hipotesis alternatif diterima (Ghozali, 2014).

\section{Analisis Jalur (Path Analysis)}

Analisis Jalur (Path Analysis) digunakan untuk menganalisis pola hubungan antar variabel dengan tujuan mengetahui pengaruh langsung dan tidak variabel bebas (exogen) terhadap variabel terikat (endogen).

Gambar 2 Analisis Jalur

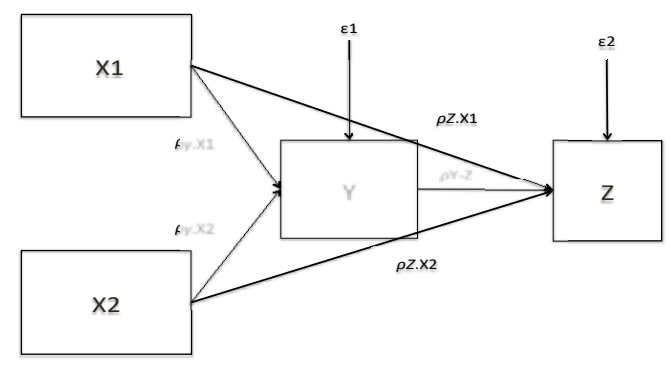

Sumber: data diolah

Berdasarkan gambar di atas didapatkan persamaan sebagai berikut:

$\mathrm{Y}=\mathrm{a}+\beta 1 \mathrm{X} 1+\beta 2 \mathrm{X} 2+\varepsilon 1$

$\mathrm{Z}=\mathrm{a}+\beta 1 \mathrm{X} 1+\beta 2 \mathrm{X} 2+\beta 3 \mathrm{Y}+\varepsilon 2$

Keterangan: 
a $\quad=$ Konstanta

$\beta \quad=$ Beta

$\mathrm{X}_{1}=$ Komunikasi Efektif (Eksogen)

$\mathrm{X}_{2} \quad=$ Koordinasi (Eksogen)

$\mathrm{Y} \quad=$ Motivasi Kerja (Intervening)

$\mathrm{Z} \quad=$ Kinerja (Endogen)

$\varepsilon=$ Error

\section{PEMBAHASAN}

\section{Hasil Uji Deskriptif}

Hasil pengolahan data diperoleh hasil statistik deskriptif sebagai berikut:

Tabel 2

Descriptive Statistics

\begin{tabular}{|l|r|r|r|}
\hline & Mean & Std. Deviation & N \\
\hline Kinerja & 37.61 & 3.897 & 100 \\
Komunikasi Efektif & 35.04 & 4.862 & 100 \\
Koordinasi & 36.19 & 4.603 & 100 \\
Motivasi Kerja & 37.21 & 3.865 & 100 \\
\hline
\end{tabular}

Sumber: SPSS

Pada Tabel 2 diketahui bahwa kinerja mempunyai nilai rata-rata sebesar 37,61, komunikasi efektif sebesar 35,04, koordinasi sebesar 36,19 dan motivasi kerja sebesr 37,21. Artinya nilai rata-rata semua variabel masuk kategori Baik (kategori 34-42).

\section{Uji Validitas dan Reliabilitas}

Dari uji validitas dapat diketahui semua instrumen (komunikasi efektif, koordinasi, motivasi kerja dan kinerja) yang digunakan dalam penelitian ini dinyatakan valid karena menghasilkan nilai $\mathrm{r}_{\text {hitung }}>\mathrm{r}_{\text {tabel }}$.

Dari uji reliabilitas diketahui bahwa nilai Cronbach Alpha lebih besar 0,6 artinya semua instrumen reliable.

$\underline{\text { Uji Asumsi }}$

Uji Normalitas
Hasil uji menunjukkan bahwa titiktitik (data) menyebar di sekitar garis diagonal dan mengikuti atau mendekati arah garis diagonal dan diartikan model regresi memenuhi asumsi normal.

\section{Uji Multikolinieritas}

Tabel 3

Uji Multikolinieritas

\begin{tabular}{lcc}
\hline Model & Tolerance & VIF \\
\hline Constant & & \\
\hline Komunikasi Efektif (X1) & 0.594 & 1.683 \\
\hline Koordinasi (X2) & 0,650 & 1.538 \\
\hline Motivasi Kerja (Z) & 0,549 & 1.821 \\
\hline Sumber: data diolah & &
\end{tabular}

Pada Tabel 3 diketahui bahwa nilai Tolerance $>0,1$ dan nilai VIF menunjukkan tidak ada satu variabel bebas yang memiliki nilai VIF $>10$. Jadi tidak ada multikolinieritas antar variabel bebas dalam model regresi.

\section{a. Uji Heteroskedastisitas}

Hasil uji menunjukkan bahwa tidak ada pola yang jelas serta titik-titik tersebut menyebar di atas dan di bawah angka 0 pada sumbu $\quad \mathrm{Y}$ sehingga tidak terjadi heteroskedastisitas.

\section{Uji Regresi Linier Berganda}

Uji regresi linier berganda menghasilkan sebagai berikut:

\section{Persamaan Regresi Berganda 1}

Tabel 4

Hasil Uji Regresi 1

\begin{tabular}{lccc}
\hline & Beta & $\mathrm{t}$ & Sig \\
\hline Komunikasi Efektif & 0,443 & 5,203 & 0,000 \\
Koordinasi & 0,350 & 4,119 & 0,000 \\
\hline
\end{tabular}

Sumber: data yang diolah $Y=14,202+0,443 X_{1}+0,350 X_{2}$

Artinya bahwa:

$\mathrm{b}_{1}=0,443$ dengan nilai sig sebesar $0,000<0,05$, artinya terdapat pengaruh positif dan 
signifikan antara Komunikasi Efektif $\left(\mathrm{X}_{1}\right)$ terhadap Motivasi Kerja $(\mathrm{Y})$.

$\mathrm{b}_{2}=0,350$ dengan nilai sig $0,000<0,05$, artinya terdapat pengaruh positif dan signifikan antara Koordinasi $\left(\mathrm{X}_{2}\right)$ terhadap Motivasi Kerja (Y).

\section{Persamaan Regresi Berganda 2}

Tabel 5

Hasil Uji Regresi Berganda 2

\begin{tabular}{lccc}
\hline & Beta & t & Sig \\
\hline Komunikasi Efektif & 0,199 & 2,676 & 0,009 \\
Koordinasi & 0,487 & 6,852 & 0,000 \\
Motivasi Kerja & 0,289 & 3,741 & 0,000 \\
\hline
\end{tabular}

Sumber: data yang diolah

$\mathrm{Z}=\mathrm{a}+\mathrm{b}_{1} \mathrm{X}_{1}+\mathrm{b}_{2} \mathrm{X}_{2}+\mathrm{b}_{3} \mathrm{Y}$

Artinya bahwa:

$\mathrm{b}_{1}=0,199$ dengan nilai sig $0,009<0,05$, artinya terdapat pengaruh positif dan signifikan antara Komunikasi Efektif $\left(\mathrm{X}_{1}\right)$ terhadap Kinerja (Z).

$\mathrm{b}_{2}=0,487$ dengan nilai sig $0,000<0,05$, artinya terdapat pengaruh positif dan signifikan antara Koordinasi $\left(\mathrm{X}_{2}\right)$ terhadap Kinerja (Z).

$b_{2}=0,289$ dengan nilai sig sebesar $0,000<0,05$, artinya bahwa terdapat pengaruh positif dan signifikan antara Motivasi Kerja (Y) terhadap Kinerja (Z).

\section{Koefisien Determinasi (Uji $R^{2}$ )}

Hasil pengujian diperoleh nilai sebagai berikut:

Tabel 6

\begin{tabular}{lcc}
\multicolumn{3}{c}{$\mathrm{Uji} \mathrm{R}^{2}$} \\
\hline Keterangan & $\mathrm{R}^{2}$ & Adjusted $\mathrm{R}^{2}$ \\
\hline Model 1 & 0,474 & 0,463 \\
\hline Model 2 & 0,684 & 0,674 \\
\hline Sumber: data diolah & &
\end{tabular}

- Model 1: Besarnya nilai $\mathrm{R}^{2}$ Square adalah 0,474 atau $47,4 \%$. Nilai $\varepsilon 1$ dihitung dengan $\sqrt{ } 1-0,474=0,725$.

- Model 2: Besarnya nilai $\mathrm{R}^{2}$ 0,684 atau $68,4 \%$. Nilai $\varepsilon 2$ dihitung dengan cara $\sqrt{ } 1$ $0,684=0,562$.

- Total $\mathrm{R}^{2}=1-(\varepsilon 1 \times \varepsilon 2)=1-(0,725 \times 0,562)=$ $1-(0,407)=0,593$ atau $59,3 \%$.

Hasil di atas mengartikan bahwa komunikasi efektif, koordinasi dan motivasi kerja mempengaruhi kinerja sebesar 59\% dan 40,7\%-nya dipengaruhi faktor lain.

\section{Uji Hipotesis}

Uji t

Diketahui nilai signifikan sebesar $0,000<0,05$ artinya secara parsial komunikasi efektif, koordinasi dan motivasi kerja mempunyai pengaruh signifikan terhadap kinerja.

\section{Uji F}

Hasil Uji F, adalah sebagai berikut:

Tabel 7

Uji F (Anova)

\begin{tabular}{lc}
\hline F hitung & Sig. \\
\hline 69,346 & 0,000 \\
\hline
\end{tabular}

Sumber: data yang diolah

Diketahui besarnya nilai $\mathrm{F}=69,346$ dengan taraf signifikansi $0,000<0,05$, artinya secara bersama-sama komunikasi efektif, koordinasi dan motivasi kerja berpengaruh signifikan terhadap kinerja.

Path Analysis (Analisis Jalur) 
Hasil analisis jalur dalam penelitian ini adalah sebagai berikut:

Gambar 3

Diagram Jalur

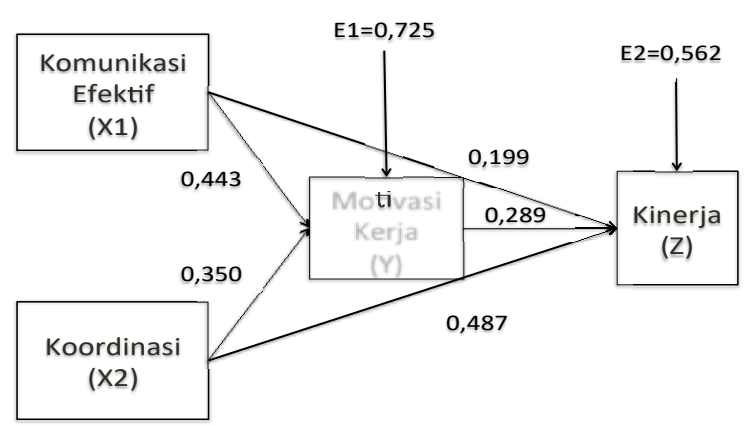

Sumber: data diolah

Gambar 3 tersebut berarti bahwa:

\section{Pengaruh Langsung}

a. Pengaruh Komunikasi Efektif $\left(\mathrm{X}_{1}\right)$ terhadap Motivasi Kerja (Y) mempunyai nilai beta 0,443 dengan sig 0,000<0,05, artinya secara langsung komunikasi efektif mempunyai pengaruh positif dan signifikan terhadap motivasi kerja.

b. Pengaruh Koordinasi $\left(\mathrm{X}_{2}\right)$ terhadap Motivasi Kerja (Y) mempunyai nilai beta sebesar 0,350 dengan sig $0,000<0,05$, artinya secara langsung koordinasi mempunyai pengaruh positif dan signifikan terhadap motivasi kerja.

c. Pengaruh Komunikasi Efektif $\left(\mathrm{X}_{1}\right)$ terhadap Kinerja (Z) mempunyai nilai beta sebesar 0,199 dengan sig 0,009<0,05, artinya secara langsung komunikasi efektif mempunyai pengaruh positif dan signifikan terhadap kinerja.

d. Pengaruh Koordinasi $\left(\mathrm{X}_{2}\right)$ terhadap Kinerja (Z) mempunyai nilai beta sebesar 0,487 dengan sig $0,000<0,05$, artinya secara langsung koordinasi mempunyai pengaruh positif dan signifikan terhadap kinerja.

e. Pengaruh Motivasi Kerja (Y) terhadap Kinerja (Z) mempunyai nilai beta sebesar 0,289 dengan sig $0,000<0,05$, artinya motivasi kerja mempunyai pengaruh langsung yang positif dan signifikan terhadap kinerja.

\section{Pengaruh Tidak Langsung}

a. Pengaruh tidak langsung Komunikasi Efektif $\left(\mathrm{X}_{1}\right)$ terhadap Kinerja $(\mathrm{Z})$ melalui Motivasi Kerja (Y) menunjukkan bahwa pengaruh Komunikasi Efektif $\left(\mathrm{X}_{1}\right)$ terhadap Motivasi Kerja (Y) sebesar 0,443 dan pengaruh Motivasi Kerja (Y) terhadap Kinerja (Z) sebesar 0,289. Hasil ini jika dikalikan $(0,443 \times 0,289=0,128)$. Hasil ini menunjukkan bahwa Motivasi Kerja (Y) tidak dapat dijadikan variabel intervening karena nilai koefisiennya lebih kecil dari nilai pengaruh langsung $(0,128<0,199)$. Artinya secara tidak langsung Komunikasi Efektif $\left(\mathrm{X}_{1}\right)$ terhadap Kinerja (Z) melalui Motivasi Kerja (Y) adalah tidak signifikan.

b. Pengaruh Koordinasi $\left(\mathrm{X}_{2}\right)$ terhadap Motivasi Kerja (Y) sebesar 0,350 dan pengaruh Motivasi Kerja (Y) terhadap Kinerja (Z) sebesar 0,289. Hasil ini jika dikalikan $(0,350 \times 0,289=0,101)$. Maka pengaruh total yang diberikan Koordinasi $\left(\mathrm{X}_{2}\right)$ terhadap Kinerja (Z) melalui Motivasi Kerja (Y) adalah 
$0,487+0,101=0,588, \quad$ artinya bahwa

Motivasi Kerja (Y) tidak dapat dijadikan sebagai variabel intervening karena nilai koefisiennya lebih kecil dari nilai pengaruh langsung $(0,101<0,487)$ artinya bahwa secara tidak langsung Koordinasi $\left(\mathrm{X}_{2}\right)$ terhadap Kinerja (Z) melalui Motivasi Kerja (Y) adalah tidak signifikan.

\section{Pengaruh Total}

Nilai pengaruh total variabel Komunikasi Efektif $\left(\mathrm{X}_{1}\right)$ terhadap Kinerja $(\mathrm{Z})$ melalui Motivasi Kerja adalah nilai pengaruh langsung sebesar 0,199 dan pengaruh tidak langsung sebesar 0,128 sehingga dapat disimpulkan bahwa pengaruh total Komunikasi Efektif $\left(\mathrm{X}_{1}\right)$ terhadap Kinerja $(\mathrm{Z})$ melalui Motivasi Kerja (Y) sebesar 0,327.

Nilai pengaruh total variabel Koordinasi $\left(\mathrm{X}_{2}\right)$ terhadap Kinerja $(\mathrm{Z})$ melalui Motivasi Kerja (Y) adalah nilai pengaruh langsung sebesar 0,487 dan pengaruh tidak langsung sebesar 0,101 sehingga dapat disimpulkan bahwa pengaruh total Koordinasi $\left(\mathrm{X}_{2}\right)$ terhadap Kinerja $(\mathrm{Z})$ melalui Motivasi Kerja (Y) sebesar 0,588.

\section{KESIMPULAN DAN SARAN \\ KESIMPULAN}

1. Komunikasi efektif berpengaruh positif dan signifikan terhadap motivasi kerja karyawan PT Garuda Indonesia (Persero) Tbk.
2. Koordinasi berpengaruh positif dan signifikan terhadap motivasi kerja karyawan PT Garuda Indonesia (Persero) Tbk.

3. Komunikasi efektif berpengaruh positif dan signifikan terhadap kinerja karyawan PT Garuda Indonesia (Persero) Tbk.

4. Koordinasi berpengaruh positif dan signifikan terhadap kinerja karyawan PT Garuda Indonesia (Persero) Tbk.

5. Motivasi kerja berpengaruh positif dan signifikan terhadap kinerja karyawan PT Garuda Indonesia (Persero) Tbk.

6. Komunikasi efektif melalui motivasi kerja berpengaruh tidak signifikan terhadap kinerja karyawan PT Garuda Indonesia (Persero) Tbk.

7. Secara tidak langsung koordinasi melalui motivasi kerja berpengaruh tidak signifikan terhadap kinerja karyawan PT Garuda Indonesia (Persero) Tbk. Nilai pengaruh total komunikasi efektif terhadap kinerja melalui motivasi kerja adalah sebesar 0,327 dan pengaruh koordinasi terhadap kinerja melalui motivasi kerja adalah sebesar 0,588 . Nilai total $R^{2}$ sebesar 0,593 atau $59,3 \%$, artinya bahwa komunikasi efektif, koordinasi dan motivasi kerja mampu menjelaskan kinerja sebesar 59\% sisanya sebesar 40,7\% dijelaskan oleh variabel lain.

\section{SARAN \\ Saran yang disampaikan setelah mengetahui hasil penelitian ini adalah:}


1. Komunikasi efektif di lingkungan PT Garuda Indonesia (Persero) Tbk ke depannya perlu mendapatkan perhatian khusus agar lebih menekankan pada REACH (respect, empathy, audible, clarity dan hamble).

2. Koordinasi di lingkungan PT Garuda Indonesia (Persero) Tbk, terus dibangun terutama antara sesama karyawan maupun dengan pimpinan sehingga memberikan manfaat pada pencapaian kinerja.

3. Dengan peningkatan pada komunikasi efektif dan koordinasi melalui motivasi kerja yang tinggi dari para karyawan PT Garuda Indonesia (Persero) Tbk, maka akan meningkatkan kinerja ke depannya.

4. Kinerja karyawan PT Garuda Indonesia (Persero) Tbk, akan lebih meningkat apabila diikuti oleh peningkatan komunikasi yang efektif, koordinasi yang baik dan motivasi kerja yang tinggi dari para karyawan.

\section{DAFTAR PUSTAKA}

Amalia, Syarah dan Mahendra Fakhri. (2016). Pengaruh Motivasi Kerja terhadap Kinerja Karyawan pada PT Gramedia Asri Media Cabang Emerald Bintaro. Jakarta: Jurnal Computech \& Bisnis. Vol.10, No.2. Des 2017 hal 119-127.

Arikunto, S. (2016). Prosedur Penelitian suatu Pendekatan Praktik. Jakarta: Rineka Cipta.

Chukwuma, E.M., \& Obiefuna, O. (2014). Effect of Motivation on Employee Productivity: A Study of Manufacturing Companies in Nnewi. Journal of Managerial Studies and Research 2 (7).
Edison. (2016). Manajemen Sumber Daya Manusia. Bandung: Alfabeta

Ghozali, Imam. (2016). Aplikasi Analisis Multivariete dengan Program IBM SPSS 23 (Edisi 8). Cetakan ke VIII. Semarang: Badan Penerbit Universitas Diponegoro.

Handayaningrat, Soewarno. (1990). Pengantar Studi Ilmu Administrasi dan Manajemen. Jakarta: Haji Masagung.

Hardjana, Agus M. (2003). Komunikasi Intrapersonal \& Komunikasi Interpersonal. Yogyakarta: Penerbit Kanisius.

Hasibuan, Malayu S.P. (2015). Manajemen Sumber Daya Manusia, Penerbit: PT. Bumi Aksara, Jakarta.

Kartono, Kartini. (2014). Pemimpin dan Kepemimpinan. Jakarta: PT Raja Grafindo Persada.

Mangkunegara, A.A Anwar Prabu. (2015). Manajemen Sumber Daya Manusia Perusahaan, Penerbit Bandung: Remaja Rosdakarya.

Miftahun dan Sugiyanto. (2010). Pengaruh dukungan social dan kepemimpinan transformasional terhadap komitmen organisasi dengan mediator motivasi kerja. Jurnal Psikologi volume 37, No. $1,94-109$.

Mulyadi. (2015). Manajemen Sumber Daya Manusia (MSDM). Bogor: In Media.

Noe, Raymond A. (2010). Manajemen Sumber Daya Manusia Mencapai Keunggulan Bersaing. Jakarta: Salemba Empat.

Priansa, Donni J. (2014). Perencanaan \& Pengembangan SDM. Bandung: Alfabeta.

Prijosaksono, Aribowo dan Roy Sembel. (2007). Komunikasi Efektif. www.sinarharapan.co.id. 
Siagian, Sondang P. (2015). Manajemen Sumber Daya Manusia. Jakarta: PT Bumi Aksara.

Sugiyono. (2012). Metode Penelitian Kuantitatif Kualitatif dan $R \& D$. Bandung: Alfabeta.

(2016). Metode Penelitian

Kuantitatif, Kualitatif dan $R \& D$. Bandung: Alfabeta.

Sutrisno, Edy. (2015). Manajemen Sumber Daya Manusia. Jakarta: Kencana.

(2016). Manajemen Sumber Daya Manusia. Bandung: PT Mulia Kencana Semesta.

Terry, George R. (2016). Manajemen Sumber Daya Manusia. Jakarta: CV Haji Masagung.

Umar, Husein. (2007), Metode Penelitian Untuk Skripsi dan Tesis Bisnis, Jakarta: PT Raja Grafindo Persada.

Yopitha, Ratih. (2015). Pengaruh Komunikasi Efektif terhadap Kinerja Karyawan PT Serpong Media Utama. Tangerang Selatan: Skripsi Univ. Pamulang. 